\title{
ARTIKELEN
}

\section{Rechtstekorten in het gezondheidsrecht}

\author{
Prof. mr. J. Legemaate*
}

\section{Inleiding}

Het is een groot genoegen juist op dit moment, bij de gelegenheid van het 50 -jarige bestaan van de Vereniging voor Gezondheidsrecht, de Henk Leenen-lezing te mogen houden. ${ }^{1}$ De collega's die de voorafgaande zeven Henk Leenen-lezingen verzorgden, kozen meestal voor het uitdiepen en bespreken van een specifiek thema. Dat doe ik niet. Vanwege dit bijzondere moment kies ik voor een bredere beschouwing, tegen de achtergrond van het preadvies dat Henk Leenen in 1968 presenteerde tijdens de eerste jaarvergadering van de Vereniging voor Gezondheidsrecht. Dat eerste preadvies droeg als titel Gezondheidsrecht - een poging tot plaatsbepaling. ${ }^{2}$ Die titel geeft kort en bondig aan waar dat eerste preadvies over ging, namelijk over de opkomst en afbakening van een nieuw vakgebied. In dit preadvies schetste Leenen de historische achtergrond van de specialisatie gezondheidsrecht, muntte hij de term gezondheidsrecht en omschreef hij de plaats van het gezondheidsrecht binnen de rechtswetenschappen en binnen de samenleving. ${ }^{3}$ Aan het slot van het preadvies stond Leenen kort stil bij de hoofdzaken waarop het nieuwe vakgebied zich zou dienen te richten. Hij sloot het preadvies af met het volgende citaat:

'De gezondheidszorg is sterk in beweging en gaat een steeds belangrijker plaats in de samenleving innemen (...). Het gezondheidsrecht is niet statisch, maar in beweging en steeds opnieuw zullen de wetenschappelijke en maatschappelijke ontwikkelingen nieuwe vraagstukken voor het gezondheidsrecht aandragen. Daarbij zal enerzijds de erkenning van de menselijke persoon een te beschermen belang zijn, anderzijds zullen ook de rechten van de samenleving goed moeten worden geregeld, opdat de collectiviteit eveneens in zijn gezondheid wordt beschermd. Ook voor de beroepsbeoefenaar is het van belang zich beschermd te weten, anderzijds moet hij de grenzen van zijn vrijheid weten en in acht nemen, hetgeen voor hem temeer van betekenis wordt, indien ook in Nederland acties tot schadevergoeding (...) meer in zwang zouden komen (...). Gezondheid en recht zijn twee belangrijke categorieën in de samenleving, die in het gezondheidsrecht samenkomen. Het recht wordt

* Johan Legemaate is hoogleraar gezondheidsrecht AMC/Universiteit van Amsterdam, en lid van de redactie van dit tijdschrift.

1 Deze achtste Henk Leenen-lezing werd uitgesproken tijdens de jaarvergadering van de Vereniging voor Gezondheidsrecht op 20 april 2018 in Rotterdam. Deze jaarvergadering stond in het teken van het 50-jarig bestaan van de vereniging.

2 Gepubliceerd in de Tijdschrift voor Sociale Geneeskunde 1968, p. 778-785.

3 Zie uitvoeriger over het preadvies: J.K.M. Gevers, 'Gezondheidsrecht - Een plaatsbepaling opnieuw beschouwd', in: J.C.J. Dute e.a. (red.), Omzien naar de toekomst - 35 jaar preadviezen Vereniging voor Gezondheidsrecht. Houten: Bohn Stafleu Van Loghum 2002, p. 11-20. 


\section{daarbij ingeschakeld bij het realiseren van een zo goed mogelijke gezondheids- zorg.'}

In het vervolg van mijn verhaal sta ik stil bij de vijf thema's die in het citaat vet gemarkeerd zijn, zij het overigens in een iets andere volgorde. Ik gebruik die thema's niet voor een analyse van 50 jaar gezondheidsrecht. Dat zou niet haalbaar zijn. Ik leg hier en daar wel een historische link, maar ik beschouw de gemarkeerde thema's vooral in het licht van recentere ontwikkelingen binnen het gezondheidsrecht. Ik concentreer mij daarbij op de vraag of er binnen het huidige gezondheidsrecht rechtstekorten zijn. Dat begrip rechtstekort vat ik in dit kader ruim op: het kan gaan om ontbrekende of gebrekkige wetgeving, om conceptuele of normatieve lacunes, maar ook om discutabele ontwikkelingen in de rechtspraak of het ontbreken van aansluiting tussen ontwikkelingen in het recht en die in de samenleving.

\section{2. 'De erkenning van de menselijke persoon'}

Wat Leenen in 1968 omschreef als 'de erkenning van de menselijke persoon' is een thema dat een belangrijke plaats innam in zijn latere werk. Deze formulering kan ook worden gezien als de opmaat naar zijn latere beschouwingen over het recht van de patiënt op zelfbeschikking. De positionering door Leenen van het recht op zelfbeschikking als een van de pijlers van het gezondheidsrecht markeert een ander jubileum dit jaar, namelijk het verschijnen 40 jaar geleden (in 1978) van de eerste druk van het toenmalige deel 1 van het Handboek gezondheidsrecht, over de rechten van de patiënt. ${ }^{4}$ In de jaren daarna ontstond een uitvoerige discussie over het recht op zelfbeschikking, zowel binnen het gezondheidsrecht als binnen de gezondheidsethiek. Die discussie spitste zich vooral toe op het rechtskarakter van het recht op zelfbeschikking, door velen toen eerder als een beginsel dan als een recht getypeerd, en minder op de concrete inhoud en betekenis daarvan. Anno 2018 mag wel eens benadrukt worden dat de cruciale betekenis van het zelfbeschikkingsrecht niet meer ter discussie staat. Zowel in het academische gezondheidsrecht als in de rechtspraak is de afgelopen decennia het uitgangspunt van zelfbeschikking breed omarmd. ${ }^{5} \mathrm{Al}$ verscheidene malen hebben zowel de Hoge Raad als lagere rechters expliciet gesproken van een recht op zelfbeschikking, ${ }^{6}$ en ook in de jurisprudentie van het Europees Hof voor de Rechten van de Mens zijn de afgelopen jaren op dat punt steeds krachtiger formuleringen te vinden. Waar gezondheidsjuristen de afgelopen decennia regelmatig verweten werd dat zij het recht op zelfbeschikking verabsoluteerden, mag er ook best nog eens op worden gewezen dat Leenen al in zijn handboek uit 1978 een evenwichtige en genuanceerde visie op het recht op zelfbeschikking gaf. Niettemin is door de jaren heen het aantal verwijzingen naar dat recht in beleidsstukken van de overheid gering gebleven. ${ }^{7}$ Des te opmerkelijker was het regeringsstandpunt uit 2016 over het onderzoek naar voltooid leven van de

4 Zie H.J.J. Leenen, Rechten van mensen in de gezondheidszorg - Een gezondheidsrechtelijke studie, Alphen aan den Rijn: Samsom 1978, p. 24-36.

5 J.K.M. Gevers, 'Gezondheidsrecht: ontwikkelingen en reflecties'. TvGR 2010, p. 363-368.

6 Zie recent Gerechtshof's-Hertogenbosch 22 maart 2018, ECLI:NL:GHSHE:2018:1240.

7 A.C. Hendriks e.a., Thematische wetsevaluatie zelfbeschikking in de zorg, Den Haag: ZonMw, 2013. 
commissie-Schnabel, in welk standpunt een zeer krachtige positie met betrekking tot autonomie en zelfbeschikking werd ingenomen. ${ }^{8}$ Waarom daar wel en in eerdere gevallen niet of nauwelijks? Kennelijk zag de regering aanleiding in dit specifieke geval aan te sluiten bij de gevoelens in de samenleving, waarin een breed draagvlak bestaat voor een voltooid leven-regeling. Dat is overigens maar een van de voorbeelden waaruit naar voren komt dat in de Nederlandse samenleving een sterk besef heerst van autonomie en zelfbeschikking. Dat werd ook duidelijk uit de maatschappelijke reacties op het wetsvoorstel van D66 over de actieve donorregistratie. In het verlengde daarvan ontspon zich ook een intens politiek debat. Met name de handelingen van de Eerste Kamer betreffende dat wetsvoorstel laten een van de meest interessante discussies over autonomie en zelfbeschikking zien die in de Nederlandse politiek ooit zijn gehouden. ${ }^{9}$

Toch is er alles overziend de afgelopen decennia maar relatief weinig moeite genomen om het door Leenen geïntroduceerde concept nader te exploreren en meer handen en voeten te geven. Hierdoor is er minder uit het zelfbeschikkingsrecht gehaald dan er naar mijn mening in zit. Het is nog steeds gebruikelijk om in beschouwingen over het zelfbeschikkingsrecht vooral te focussen op het karakter van zelfbeschikking als afweerrecht. Er zijn aan dat recht echter ook andere dimensies te onderkennen. Te denken valt aan zelfbeschikking als keuzevrijheid en aan zelfbeschikking als vermogen om het eigen leven vorm te geven. ${ }^{10}$ Deze dimensies van het zelfbeschikkingsrecht hebben tot op heden niet de aandacht gekregen die zij verdienen. Dat rechtstekort speelt ons parten in verschillende juridische discussies, of het nu gaat om het realiseren van nieuwe wetgeving over het toepassen van drang en dwang in de gezondheidszorg, om de vraag hoe de positie van kwetsbare mensen juridisch het beste kan worden beschermd of om de ruimte die er is om in het kader van het zorgstelsel betekenis toe te kennen aan individuele keuzen die patiënten willen maken. ${ }^{11}$ Van dat laatste is de recente rechtszaak van een zwangere patiënte tegen het Bravis-ziekenhuis een illustratief voorbeeld. In deze zaak gaat het om een zwangere patiente met een medische indicatie, die vorderde dat zij in het ziekenhuis mocht bevallen onder begeleiding van haar eigen, niet aan het ziekenhuis verbonden verloskundige. De rechter wees deze vordering af. ${ }^{12}$ In een hoofdredactioneel commentaar in Trouw op deze procedure viel te lezen dat het inwilligen van de vordering van patiënte het ziekenhuis feitelijk zou degraderen tot een verhuurplek. ${ }^{13} \mathrm{Op}$ dezelfde dag werd in een ingezonden reactie in diezelfde krant juist benadrukt dat keuzevrijheid in de geboortezorg belangrijk is omdat die de mogelijkheid biedt om zorg op de individuele behoeften en risico's van vrouwen aan te passen en omdat de mogelijkheid tot kiezen op zichzelf al kan leiden tot een wezenlijk betere beleving van de bevalling. ${ }^{14}$ Moeten we niet concluderen dat we in de context van het zorgstelsel de patiënt veel te strak hebben ingesnoerd in professionele standaarden en kwaliteitsindicatoren? Wordt vaak niet te gemakkelijk aangenomen dat preferenties van patiënten in de zorg niet het laatste woord kunnen zijn? Is het terecht dat

$8 \quad$ Kamerstukken II 2016/17, 32647, 55.

9 Zie de Handelingen Eerste Kamer van 30 januari en 6 februari 2018.

10 Hendriks e.a. (2013), p. 43-46.

11 Over dat laatste aspect: Hendriks e.a. (2013), p. 109-119.

12 Rechtbank Zeeland-West-Brabant 23 maart 2018, ECLI:NL:RBZWB:2018:1745.

13 Trouw van 13 maart 2018.

14 E. Kingma, 'Geboortezorg is óók zorg voor moeders', Trouw, 13 maart 2018. 
het uitoefenen van zelfbeschikking in deze context vaak wordt gezien als een bedreiging voor de solidariteit? Het is de vraag of de Bravis-casus geschikt was om deze vragen juridisch uit te vechten, maar het gaat wel om prangende vragen. Hoe vaak lezen we niet in beleidsvisies van de overheid en van zorginstellingen dat de patiënt centraal staat, maar is dat ook werkelijk zo? Het probleem is dat we voor het erkennen en realiseren van keuzevrijheid en zelfbeschikking in de context van het recht op zorg nauwelijks een referentiekader hebben ontwikkeld. Zoals we dat ook niet hebben voor het omgaan met mensen die niet of minder goed tot zelfbeschikking in staat zijn. Wetgeving heeft nogal eens de neiging gericht te zijn op de burger als vrije, zelfbeschikkende mens, die op basis van adequate informatie tot een weloverwogen keuze komt. Maar geven we daarmee ook goede rechtsbescherming aan mensen met lage gezondheidsvaardigheden, aan psychiatrische patiënten in de context van bemoeizorg, aan kwetsbare ouderen en aan andere mensen die veel minder zelfredzaam zijn dan de beleidsretoriek over de participatiesamenleving ons wil doen geloven? Ik ben op het antwoord op die vragen niet gerust.

Soms zijn er ook andere aanleidingen om aspecten van de geldende wetgeving ter discussie te stellen. Ik denk aan het systeem van leeftijdsgrenzen met betrekking tot besluitvorming door minderjarigen in de gezondheidszorg. Te begrijpen valt dat de wetgever eertijds voor die leeftijdsgrenzen heeft gekozen, vooral in het belang van de rechtszekerheid. Het is zeker zo dat die huidige leeftijdgrenzen minderjarigen vanaf 12 jaar al de nodige zeggenschap geven. In twee recente zaken, die van de 12 -jarige jongen die een chemobehandeling weigerde ${ }^{15}$ en die betreffende de medische situatie van Ajax-voetballer Nouri ${ }^{16}$ werd duidelijk dat velen in de samenleving de nu al in de wet geregelde zeggenschap van minderjarigen niet vanzelfsprekend vonden of zich die zeggenschap in elk geval niet hadden gerealiseerd. Dat is kennelijk een thema waar het intensiveren van voorlichting over de huidige juridische kaders geen kwaad kan. Maar afgezien daarvan komt de vraag op of die huidige leeftijdsgrenzen toch niet knellen, bijvoorbeeld ook in het licht van de bepalingen van het VN-verdrag inzake de rechten van het kind. Het is de moeite waard om op dit punt te kijken naar de Belgische patiëntenrechtenwetgeving, waarin niet de leeftijd, maar de wilsbekwaamheid van de minderjarige centraal staat, en om in dat licht te bezien of ons huidige systeem van leeftijdsgrenzen zich alles afwegend nog wel verdraagt met het recht op zelfbeschikking van minderjarigen. ${ }^{17}$ Dat zou ook een mooi onderwerp zijn voor een thematische wetsevaluatie. Ook een zo intens met zelfbeschikking verbonden concept als informed consent is naar mijn mening aan herijking toe, zowel waar het gaat om de uitvoeringspraktijk als om de regelgeving. Het lijkt erop dat informed consent toch in veel gevallen als een formele stap wordt gezien, die nu eenmaal gezet moet worden. Daardoor kunnen kansen worden gemist om te exploreren wat de werkelijke wensen en gedachten van een patiënt zijn, teneinde een zo goed mogelijke match te krijgen tussen de behoefte van de patiënt en de te verlenen zorg. Het is typerend dat de daarop betrekking hebbende methodiek van de shared decisionmaking doorgaans wordt gezien als een ethische inter-

17 F.M. de Kievit, 'Wie beslist? De autonomie van minderjarigen in het geven van toestemming voor een medische behandeling', Tijdschrift voor Familie- en Jeugdrecht 2018/16. Zie ook J. Dorscheidt, 'Medische behandeling en de wilsbekwaamheid van minderjarige patiënten', Ars Aequi 2018, p. 289-295. 
ventie, en in die context als een innovatie wordt beschouwd. In het licht van het zelfbeschikkingsrecht komt aan shared decisionmaking echter ook in het juridische domein betekenis toe. Informed consent is een gelaagd begrip. Uiteindelijk moet natuurlijk formeel komen vast te staan dat de patiënt voldoende geïnformeerd is en welk besluit hij neemt, maar minstens zo belangrijk is dat dat geschiedt op een wijze die gericht is op het expliciteren en verdisconteren van de voorkeuren, overtuigingen en omstandigheden van de patient. Dat vergt een bepaalde benadering in de praktijk van de gezondheidszorg, maar kan ook worden ondersteund door wetgeving. Inspiratie daarvoor kan bijvoorbeeld worden gevonden in de Amerikaanse Patient Protection and Affordable Care Act, beter bekend als 'Obamacare'. 18

Vanuit een meer historisch perspectief bezien zijn er natuurlijk ook tal van onderwerpen waar op het punt van de rechtspositie van de patiënt belangrijke vooruitgang is geboekt. Moest er tot in de jaren negentig van de vorige eeuw nog een felle strijd gevoerd worden over het recht van een patiënt om zelf zijn dossier te mogen inzien, we naderen nu het moment waarop iedere burger, gezeten aan zijn eigen keukentafel, digitaal zijn medische dossiers kan raadplegen. ${ }^{19}$ De discussie of het moet gaan om real time inzage dan wel om inzage met een vertraging van enkele dagen of weken beschouw ik als een achterhoedegevecht. De eerste ervaringen met real time inzage wijzen uit dat zonder problemen voor die optie gekozen kan worden. ${ }^{20}$ En gezien vanuit een optiek van zelfbeschikking ligt dat ook voor de hand.

\section{3. 'Ook de beroepsbeoefenaar moet zich beschermd weten'}

Over beroepsbeoefenaren merkte Leenen in 1968 op: 'Ook voor de beroepsbeoefenaar is het van belang zich beschermd te weten, anderzijds moet hij de grenzen van zijn vrijheid weten en in acht nemen'. Waar het gaat om de beroepsbeoefenaar is het in de eerste plaats van belang erop te wijzen dat de betekenis van de kennis en de houding van beroepsbeoefenaren voor de realisatie van gezondheidsrechtelijke regels en normen maar moeilijk kan worden overschat. Voor veel van die regels en normen geldt dat deze alleen tot hun recht komen als beroepsbeoefenaren van deze regels weet hebben, al dan niet op basis van onderwijs of advies, en ze toepassen. In tal van situaties gaat dat prima. In andere gevallen niet, zoals onder meer bleek uit de recente publiciteit over het onbevoegd inzien van een dossier van realityster Samantha de Jong in het Haga-Ziekenhuis. ${ }^{21}$ Algemeen bekend is dat dergelijke praktijken niet alleen in het Haga-Ziekenhuis voorkomen. Deze situaties laten zien dat een professionele houding van beroepsbeoefenaren niet altijd een vanzelfsprekendheid is. Het blijft belangrijk daaraan aandacht te blijven geven, onder meer in het

18 J. Legemaate, Nieuwe verhoudingen in de spreekkamer (achtergrondstudie RVZ-advies). Amsterdam: AMC, 2013, p. 8.

19 Uit een in april 2018 door het NIVEL gepubliceerd onderzoek bleek overigens dat ongeveer 20\% van de patienten niet bekend is met het recht om het eigen dossier in te zien (https://www.skipr.nl/actueel/id34383-eenvijfde-patienten-niet-bekend-met-inzagerecht-medisch-dossier.html). Ook op dit punt is betere voorlichting nodig.

20 E. Verstraete e.a., 'Is de patiënt gebaat bij directe inzage in zijn dossier? - Evaluatie van het patiëntenportaal in het UMC Utrecht', Nederlands Tijdschrift voor Geneeskunde 2016, D325. Terughoudender zijn Y. Smulders en S. Metselaar, 'Directe inzage in epd niet in belang van patiënt', Medisch Contact 2017, nr. 22, p. 34-35.

21 Zie https://www.ad.nl/show/hagaziekenhuis-schrikt-van-inbreuk-medisch-dossier-barbie a5414302/. 
kader van het onderwijs. Soms gaat het ook om situaties met een meer structureel karakter. Als plaatsvervangend lid van de METC van het AMC verbaas ik me elke vergadering weer over zeer ingewikkelde en onleesbare patiënteninformatiefolders (PIF's) die artsen en onderzoekers aan proefpersonen willen voorleggen. Het is goed dat de METC daar vaak een stokje voor kan steken, maar het is veelzeggend en treurig tegelijk dat bijna 20 jaar na de inwerkingtreding van de Wet medisch-wetenschappelijk onderzoek met mensen (WMO), en drie wetsevaluaties verder, ${ }^{22}$ dit nog steeds een probleem is. Dit ondermijnt de inhoud en bedoeling van artikel $6 \mathrm{WMO}$, waarin onder meer is geregeld dat de informatie op een zodanige wijze aan de proefpersoon wordt verstrekt, dat redelijkerwijs zeker is dat hij deze naar haar inhoud heeft begrepen.

Ook waar het gaat om de rechtspositie van beroepsbeoefenaren in de gezondheidszorg hebben zich de afgelopen decennia belangrijke ontwikkelingen voorgedaan. Cruciaal was in 1995 de komst van de Wgbo, vanwege de duale doelstelling van deze wet: enerzijds het versterken en verduidelijken van de rechtspositie van de patiënt, anderzijds het benadrukken van de eigen verantwoordelijkheid van de beroepsbeoefenaar, op basis van de professionele standaard. De Wgbo en de Wet BIG vormden en vormen nog steeds een adequaat kader voor de juridische positie van beroepsbeoefenaren. Waar zich de noodzaak voordeed om die positie extra te beschermen, heeft de wetgever nadere stappen gezet, bijvoorbeeld door het opnemen in de Wet kwaliteit, klachten en geschillen zorg van een regeling inzake het veilig melden van incidenten in het kader van interne kwaliteitssystemen. Maar aan dergelijke ontwikkelingen is wel een grens. Recente pleidooien om die veilig meldenregeling uit te breiden naar calamiteiten onderschrijf ik niet. ${ }^{23}$ Een dergelijke stap zou de balans tussen de noodzakelijke bescherming van beroepsbeoefenaren en het belang van externe verantwoording verstoren. Dat kan ertoe leiden dat het publieke vertrouwen in de kwaliteitssystemen van de gezondheidszorg nog meer onder druk komt te staan dan nu al het geval is. Nog te vaak wordt er uit de kring van beroepsbeoefenaren en hun organisaties gepleit voor juridische stappen die een defensieve achtergrond hebben en die door het publiek zouden kunnen worden begrepen als een roep om bepaalde vormen van immuniteit. Ik wijs in dat kader ook op de ophef die ontstond toen onlangs bekend werd dat het Openbaar Ministerie (OM) heeft besloten in vier euthanasiezaken een nader onderzoek in te stellen. ${ }^{24}$ De kritiek op het OM in de voorbije jaren luidde nu juist dat het OM dit sinds de inwerkingtreding van de euthanasiewet in 2002 in geen enkele zaak heeft gedaan. Het is natuurlijk zo dat het OM met deze bevoegdheid prudent moet omgaan, in het belang van de meldingsbereidheid, en het is inderdaad opmerkelijk dat het OM nu vier recente gevallen tegelijk in onderzoek neemt, maar de soms heftige reacties op de stap als zodanig zijn naar mijn mening niet gerechtvaardigd.

Hier bereiken we de grenzen van de vrijheid van de hulpverlener, zoals Leenen het in het preadvies van 1968 formuleerde. Dit is ook aan de orde op het terrein van de openheid inzake fouten en incidenten. Op dat gebied heeft de zorgsector de afgelopen jaren belang-

22 Zie M.C. Ploem e.a., Derde evaluatie Wet medisch-wetenschappelijk onderzoek met mensen. Den Haag: ZonMw, 2018, p. 11-12 en p. 89-112.

23 Zie I. Meynaar e.a., 'Melder calamiteit verdient bescherming', Medisch Contact 2018, nr. 5, p. 18-20 en J. Legemaate, “Just culture' en het afleggen van verantwoording'. TvGR 2018, p. 107-108.

24 Zie https://www.nrc.nl/nieuws/2018/03/08/het-om-wil-nu-zelf-grenzen-euthanasie-onderzoeken-a1594903. 
rijke stappen vooruit gezet, ${ }^{25}$ maar op tal van momenten is ook de weerstand tegen meer openheid nog goed voelbaar, onder zowel beroepsbeoefenaren als juristen. Niet zelden is die weerstand gebaseerd op een onterechte vrees voor juridische repercussies. Tot voor kort was het niet ongebruikelijk om in deze context de patiënt of zijn familie een zwijgcontract op te dringen, een praktijk waaraan naar ik hoop nu toch echt een einde is gekomen. ${ }^{26}$ Waar het gaat om openheid is er wat mij betreft maar één valide adagium, en dat luidt: volle kracht vooruit. Het maximaliseren van openheid is onder alle omstandigheden een win-winsituatie. Het is goed dat de NFU, en in navolging daarvan ook de NVZ, recentelijk stappen hebben gezet om opener te zijn over calamiteiten. ${ }^{27}$ Maar in de redenen om dat te doen klinkt nog te zeer een defensieve opstelling door. En met betrekking tot de wijze waarop zou wel eens sprake kunnen zijn van 'too little, too late'. Wat pleit er anno 2018 tegen dat ziekenhuizen samenvattingen van calamiteitenrapportages, maar bijvoorbeeld ook van kwaliteitsvisitaties, op de website zetten? Ik zie daar geen enkele reële belemmering voor. Beroepsbeoefenaren en zorginstellingen hebben de afgelopen jaren terecht gepleit voor een 'just culture', in het belang van de kwaliteitsverbetering in de zorg. ${ }^{28}$ Maar de noodzakelijke pendant daarvan is een 'just culture' gericht op het belang van de individuele patiënt en op het herwinnen en behouden van het publieke vertrouwen in de wijze waarop de zorgsector omgaat met dingen die mis gaan. Ik heb de indruk dat er nogal eens wordt miskend dat het een niet zonder het ander kan.

Zijn er dan geen ontwikkelingen die, waar het gaat om de positie van beroepsbeoefenaren, als een onbalans kunnen worden gezien? Moeten we ons bijvoorbeeld niet iets aantrekken van de aanzwellende kritiek dat het tuchtrecht een steeds punitiever karakter krijgt? ${ }^{29}$ In het algemeen gesproken ben ik het met die kritiek niet eens, ook niet waar het gaat om het wetsvoorstel tot aanpassing van het tuchtrecht dat de Tweede Kamer onlangs heeft aangenomen. ${ }^{30}$ Het komt mij voor dat de inhoud van dat wetsvoorstel behoorlijk goed aansluit bij de doelstellingen van het tuchtrecht, bijvoorbeeld ook op het punt van het in de wet opnemen van de zogenaamde LOBB, de last tot onmiddellijke beëindiging van de beroepsuitoefening. ${ }^{31}$ Kritiek verdient wel de maatregel die alweer enkele jaren geleden in de Wet BIG werd opgenomen, namelijk de openbaarmaking van een tuchtrechtelijke berisping. Dat is een wettelijke bepaling waarover moet worden geconcludeerd dat deze inhoudelijk zinloos is en, in termen van effecten, disproportioneel. Het is een illusie te denken dat door het publiceren van berispingen aan de patiënt relevante kwaliteitsinformatie wordt verschaft. ${ }^{32}$ Een beroepsbeoefenaar die in een concrete casus een tuchtrechtelijke berisping heeft gekregen, kan nog steeds een uitstekende beroepsbeoefenaar zijn. Het in alle gevallen

25 Zie voor een overzicht www.openindezorg.nl.

26 J. Legemaate, 'Zwijgcontracten in de zorg', Ars Aequi 2016, p. 702-704.

27 Zie http://www.nfu.nl/actueel/leren-van-dingen-die-misgaan-in-de-zorg.

28 M.S. de Vos e.a., 'Hoe we beter en veilig kunnen leren van calamiteiten', Nederlands Tijdschrift voor Geneeskunde 2017, D1090.

29 Zie bijvoorbeeld G. Jager, 'Van berisping of waarschuwing leer je niks - Tuchtrecht moet gaan om herstel en niet om bestraffen', Medisch Contact 2017, nr. 41, p. 20-22. Eerder ook: A.C. Hendriks, 'Tuchtrecht - Meer tucht dan recht', TvGR 2015, p. 322-330.

30 Wetsvoorstel 34629.

31 Eén aspect van dit voorstel is wel problematisch, namelijk het invoeren van een door de klager te betalen griffierecht.

32 J. Legemaate. 'Het recht op non-informatie', NJB 2011, p. 873-874. 
openbaar maken van berispingen doet meer kwaad dan goed, zoals ook kan worden afgeleid uit het in 2017 hierover gepubliceerde NIVEL-onderzoek. ${ }^{33}$ Hier is een veel afgewogener benadering op zijn plaats, zoals deze bijvoorbeeld is te vinden in artikel 48 lid 5 van de Advocatenwet. Dit wetsartikel bepaalt dat de raad van discipline kan besluiten een berisping openbaar te maken, als een door het tuchtrecht beschermd belang dat vordert. Dat is geen moeten, maar kunnen. Het is een goede zaak dat de Tweede Kamer in april 2018, door het aannemen van een amendement betreffende wetsvoorstel 34629, ook de Wet BIG in deze zin heeft gewijzigd. ${ }^{34}$

\section{4. 'De rechten van de samenleving'}

In zijn preadvies uit 1968 stelde Leenen dat 'ook de rechten van de samenleving goed moeten worden geregeld, opdat de collectiviteit eveneens in zijn gezondheid wordt beschermd'. Binnen het gezondheidsrecht heeft dat gestalte gekregen in verschillende wettelijke regelingen. Te denken valt in algemene zin aan de regelgeving betreffende de wettelijke aanspraken op zorg (waaronder begrepen preventie), en in meer specifieke situaties aan de plicht voor artsen om besmettelijke ziekten te melden, als geregeld in de Wet publieke gezondheid, en aan de mogelijkheid om dwang toe te passen met betrekking tot patiënten die ten gevolge van een psychische stoornis een gevaar voor anderen veroorzaken, als geregeld in de Wet Bopz. Het maken van een afweging tussen de belangen en rechten van de individuele patiënt en die van anderen of van de samenleving speelt ook binnen het gezondheidsrecht vanouds een grote rol. Wel zijn de redenen om een dergelijke afweging te maken duidelijk verschoven. Ging het Leenen in 1968 dus nog vooral om de gezondheid van de collectiviteit, heden ten dage staan andere aspecten van het algemeen belang centraal, zoals het tegengaan van zorgfraude en het bevorderen van maatschappelijke veiligheid. Hoezeer dat kan leiden tot debatten en ontwikkelingen die op te eenzijdige keuzen en afwegingen zijn gebaseerd, blijkt onder meer uit het verloop van de parlementaire behandelingen van de Wet verplichte ggz, de Wet zorg en dwang en de Wet forensische zorg. Gelukkig trok de Tweede Kamer op een aantal punten tijdig aan de rem, bijvoorbeeld door niet akkoord te gaan met het in de Wet verplichte ggz opnemen van een omstreden observatiemaatregel, maar de genoemde wetten bevatten nog tal van andere elementen die duidelijk zijn ingegeven door de wens om het belang van de samenleving te beschermen, maar zonder dat, in het licht van de in acht te nemen normatieve uitgangspunten, sprake is van een goede onderbouwing. Een vergelijkbare ontwikkeling doet zich voor op het terrein van het beroepsgeheim. Was dat beroepsgeheim eeuwenlang een onomstreden en rustig bezit, de laatste jaren tuimelen de voorstellen tot beperking van het beroepsgeheim over elkaar heen. Vaak vormt de wens om het algemeen belang te beschermen een rode draad. Het is interessant om te zien hoe de Hoge Raad, onder de vlag van de zogenaamde 'zeer uitzonderlijke omstandigheden', de afgelopen jaren een omvangrijke

33 R. Friele e.a., Zorgverleners en burgers over het openbaar maken van door de tuchtrechter opgelegde berispingen en geldboetes, Utrecht: NIVEL, 2017.

34 Het amendement werd ingediend op 19 april 2018 en aangenomen op 24 april 2018 (Kamerstukken II $2017 / 18,34629,13)$. 
jurisprudentie heeft ontwikkeld met betrekking tot het beroepsgeheim. ${ }^{35}$ Die jurisprudentie gaat deels over beperking van het beroepsgeheim in het algemeen belang, bijvoorbeeld in het geval van fraude met declaraties door een arts of een apotheker. Dat is ook de achtergrond van de wettelijke mogelijkheden van zorgverzekeraars en de Nederlandse Zorgautoriteit om, op grond van de Zorgverzekeringswet respectievelijk de Wet Marktordening Gezondheidszorg, onder specifieke omstandigheden patiëntendossiers te kunnen inzien. Een laatste loot aan deze stam is het in 2016 tot stand gekomen Convenant fraude in de zorg, welk convenant de zogenaamde ODA introduceert, de onafhankelijk deskundige arts. Deze ODA kan bij signalen en verdenkingen van fraude een rol spelen bij het zoveel mogelijk overeind houden van het beroepsgeheim. Naast fraudebestrijding vormen ook het beschermen van de maatschappelijke veiligheid en het opsporen of berechten van strafbare feiten steeds vaker een grond om het beroepsgeheim te beperken. In drie recente regelingen zijn daarover bepalingen opgenomen. Het gaat om de regeling inzake de weigerachtige observandus in de Wet forensische zorg, ${ }^{36}$ de mogelijke toegang van justitie tot biobanken als geregeld in het conceptwetsvoorstel zeggenschap lichaamsmateriaal ${ }^{37}$ en de mogelijkheden voor de AIVD en de MIVD om kennis te kunnen nemen van medische gegevens op basis van de nieuwe Wet op de inlichtingen- en veiligheidsdiensten, beter bekend als de 'sleepwet'. ${ }^{38}$ Het is bepaald niet zo dat met betrekking tot al deze regelingen een afgewogen discussie over het belang van het beroepsgeheim heeft plaatsgevonden. Dat is ook niet het geval in de reparatiebrief over de 'sleepwet' die het kabinet op 6 april naar de Tweede Kamer zond, in reactie op de uitslag van het op 21 maart gehouden referendum. ${ }^{39}$ Ook in een onlangs bij de Tweede Kamer ingediende wijziging van de Wet foetaal weefsel wordt ruimte gecreëerd om onder die wet vallend weefsel te bewaren voor opsporingsdoeleinden, ${ }^{40}$ maar dat gaat over de bijzondere situatie dat de vrouw van wie het weefsel afkomstig is slachtoffer is van een zeden- of geweldsdelict. In alle andere gevallen die ik noemde staat de maatschappelijke veiligheid centraal, en wordt daarin een rechtvaardiging gevonden om de reikwijdte van het beroepsgeheim te beperken. $\mathrm{Nu}$ is het niet zo dat alle voorstellen en regelingen met betrekking tot het tegengaan van zorgfraude en het bevorderen van de maatschappelijke veiligheid per definitie onzinnig of onverdedigbaar zijn, maar het kennelijke gemak waarmee het beroepsgeheim steeds vaker aan dergelijke doelen wordt opgeofferd geeft ernstig te denken. Van een zorgvuldige afweging van de verschillende belangen die in dergelijke situaties aan de orde zijn, is lang niet altijd sprake. Dat leidt ertoe dat in discussies over de verhouding tussen de rechten van het individu en de rechten van anderen en die van de samenleving ad hoc beslissingen worden genomen of dat bij het realiseren van wettelijke regelingen belangrijke onderliggende uitgangspunten en beginselen niet voldoende in acht worden genomen. Bij het realiseren en aanpassen van de wetgeving is het van belang dat de hieraan ten grondslag liggende individuele en algemene

35 J. Legemaate, 'Beroepsgeheim en verschoningsrecht in de gezondheidszorg - Enkele beschouwingen naar aanleiding van de rechtspraak van de Hoge Raad'. NJB 2009, p. 2619-2626.

36 E.J.C. de Jong, 'Over tbs, de weigerende observandus en het verschoningsrecht', TvGR 2012, p. 406-413.

37 D.J.P. van Barneveld en W.R. Kastelein, 'Strafvorderlijke bepalingen Wetsvoorstel zeggenschap lichaamsmateriaal', TvGR 2017, p. 310-330.

38 Zie https://www.knmg.nl/actualiteit-opinie/nieuws/nieuwsbericht/nieuwe-sleepwet-beperkt-beroepsgeheim. htm.

39 Kamerstukken II 2017/18, 34270, 70.

40 Wetsvoorstel 34893. 
belangen duidelijk worden benoemd en gewogen. Waar lange tijd een dereguleringstoets gebruikelijk was, bekruipt mij steeds vaker de gedachte dat bij het ontwikkelen van wetgeving een grondrechtentoets zou moeten worden voorgeschreven. We moeten ons blijven realiseren dat wetgeving, naast beleidsinstrument, ook drager is van het recht en van morele waarden, door de rechten van de burgers te waarborgen en hen bescherming te bieden. Die rol kan de wet alleen vervullen als keuzes, overwegingen en rechtsvragen worden geëxpliciteerd en worden geplaatst in het licht van de relevante kernwaarden en rechtsbeginselen. Alleen dan kan worden voorkomen dat beginselen gericht op de individuele vrijheid het stelselmatig moeten afleggen tegen argumenten in de sfeer van veiligheid en efficiency. ${ }^{41}$

\section{5. 'Het recht en een zo goed mogelijke gezondheidszorg'}

Waartoe is het gezondheidsrecht op aarde? Aan het slot van zijn preadvies uit 1968 zei Leenen daarover het volgende: 'Gezondheid en recht zijn twee belangrijke categorieën in de samenleving, die in het gezondheidsrecht samenkomen. Het recht wordt daarbij ingeschakeld bij het realiseren van een zo goed mogelijke gezondheidszorg.' Wellicht is die laatste zin nog wel de beste uitdrukking in het preadvies van de geest van 1968. Je zou kunnen zeggen dat uit die laatste zin een nogal instrumentele visie op het recht spreekt, maar ook dat die zin idealisme ademt. Of is deze zin een aanwijzing dat Leenen een early adaptor was van de beweging die vooral in de jaren zeventig van de vorige eeuw geloofde in de maakbaarheid van de samenleving, in dit geval door middel van het recht? Het punt is natuurlijk: wanneer kan er gesproken worden van een 'zo goed mogelijke gezondheidszorg'? Het maakt nogal uit of je dat begrip benadert vanuit de individuele patiënt of vanuit de belangen van de samenleving. En hoe reëel is het dat de belangen en functies van het recht en die van een goede gezondheidszorg altijd samenvallen?

De voorbije decennia hebben ons geleerd dat het belang en de maatschappelijke betekenis van het gezondheidsrecht groot is, maar ook dat de invloed van het recht niet moet worden overschat. Als het gaat om het sturen van de interactie tussen patiënt en hulpverlener, presteert wetgeving matig tot slecht. ${ }^{42}$ En ook in de gezondheidszorg zijn voorbeelden van 'gratuit recht' te vinden: het door de politiek toekennen van rechten als goedkope manier om aan verwachtingen van burgers te voldoen. ${ }^{43}$ De talrijke wetsevaluaties die de afgelopen jaren in de gezondheidszorg zijn uitgevoerd, laten daarvan diverse voorbeelden zien. Dan blijkt bijvoorbeeld ook dat rechten die niet zijn voorzien van een financiële onderbouwing, of die moeten worden gerealiseerd in zorgsectoren waar organisatie en afstemming te wensen overlaten, vaak weinig voorstellen. Zo betekent het formuleren van een recht op zorg niet dat wachtlijsten verdwijnen. Een schrijnend voorbeeld is dat een ggzpatiënt anno 2018 een heel goed omschreven recht op zorg heeft, maar dat de huidige praktijk een heel ander beeld laat zien. Wetsevaluaties leveren ook voorbeelden op van

41 J. Legemaate, 'Wikken en wegen' (oratie UvA 2011), in: Oratiebundel Gezondheidsrecht, Den Haag: Sdu Uitgevers, 2012, p. 430-432.

42 Zie bijv. R. Friele en R. Coppen, 'Wetgeving en de positie van de patiënt: instrument voor verandering of terugvaloptie?', Recht der Werkelijkheid 2010, nr. 3, p. 26-39.

43 B. Niemeijer en N. Huls, 'Zorg en recht: een ongelukkig begrippenpaar', Recht der Werkelijkheid 2010, nr. 3, p. $91-100$. 
routineuze wetstoepassing, die met de door de wet beoogde doelen niet veel meer te maken heeft. Door een te eenzijdige focus op juridische interventies kunnen de echte problemen van de patiënt makkelijk uit beeld raken. Leenen schreef dus in 1968: 'Het recht wordt daarbij ingeschakeld bij het realiseren van een zo goed mogelijke gezondheidszorg'. Ik heb eigenlijk wel heel veel sympathie voor die slotzin van zijn preadvies, niet alleen wanneer je daarnaar kijkt in het licht van het toen net in ontwikkeling zijnde vakgebied gezondheidsrecht, maar ook in de huidige tijd, in het jaar waarin de vereniging 50 jaar bestaat. Maar we moeten ons ervan bewust blijven dat de praktijk van de gezondheidszorg complex en weerbarstig is, en dat het belangrijk is steeds opnieuw de vraag te stellen op welke manieren de binnen het gezondheidsrecht als belangrijk ervaren normen en regels in de praktijk het beste kunnen worden verwerkelijkt. In een sector waar persoonlijke betrokkenheid en vertrouwen nog steeds een grote rol spelen, is en blijft dat essentieel.

\section{Afronding}

'Het gezondheidsrecht is niet statisch, maar in beweging en steeds opnieuw zullen de wetenschappelijke en maatschappelijke ontwikkelingen nieuwe vraagstukken voor het gezondheidsrecht aandragen'. Deze woorden van Leenen uit 1968 zijn onverminderd waar. Daarvan getuigen ook de preadviezen die dit jaar aan de vereniging zijn uitgebracht, over enkele nieuwe technologische ontwikkelingen in de zorg. ${ }^{44}$ Die preadviezen zijn een goede illustratie van de enorme ontwikkeling die het gezondheidsrecht heeft doorgemaakt sinds de start van deze vereniging, maar laten ook zien dat fundamentele vragen die Leenen al in 1968 stelde onverminderd belangrijk zijn, met name waar het gaat om de relatie tussen het recht en maatschappelijke of technologische ontwikkelingen en om de invloed die ontwikkelingen in de gezondheidszorg hebben op de samenleving als geheel. Ook beide preadviezen leggen tal van rechtstekorten bloot. Aan deze en andere rechtstekorten zal vanuit het gezondheidsrecht gewerkt moeten blijven worden. De eerste die binnen het gezondheidsrecht het begrip rechtstekort gebruikte, was hoogleraar Bernhard Sluijters. In zijn oratie uit 1985 merkte hij op: 'Overal vertoont het recht tekorten, maar op het terrein van de gezondheidszorg zijn die tekorten (...) wel bijzonder menigvuldig en bovendien zeer nijpend en schrijnend. ${ }^{45}$ Zo erg is het naar mijn mening nu niet meer, maar er is op het gebied van het gezondheidsrecht nog genoeg te doen, zowel waar het gaat om conceptualisering, het verdiepen en uitwerken van normatieve grondslagen en beginselen als om de rechtsbeoefening en rechtshandhaving in de dagelijkse praktijk.

44 Onder de overkoepelende titel Nieuwe techniek, nieuwe zorg. Den Haag, Sdu 2018 (auteurs E.J. Oldekamp, M.C. de Vries en M.F. van der Mersch).

45 B. Sluijters, 'Geknipt verband' (oratie RU Leiden 1985), in: Oratiebundel Gezondheidsrecht. Den Haag: Sdu Uitgevers, 2012, p. 138. 